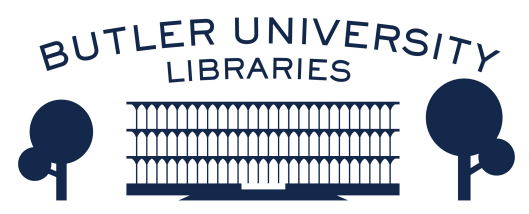

Journal of Hindu-Christian Studies

Volume 6

Article 13

January 1993

\title{
Book Reviews: "The Unity of Reality: God, God-Experience, and Meditation in the Hindu-Christian Dialogue"
}

Bede Griffiths

Michael Stoeber

Follow this and additional works at: https://digitalcommons.butler.edu/jhcs

Part of the Religion Commons

\section{Recommended Citation}

Griffiths, Bede and Stoeber, Michael (1993) "Book Reviews: "The Unity of Reality: God, God-Experience, and Meditation in the Hindu-Christian Dialogue"," Journal of Hindu-Christian Studies: Vol. 6, Article 13.

Available at: https://doi.org/10.7825/2164-6279.1082

The Journal of Hindu-Christian Studies is a publication of the Society for Hindu-Christian Studies. The digital version is made available by Digital Commons @ Butler University. For questions about the Journal or the Society, please contact cbauman@butler.edu. For more information about Digital Commons @ Butler University, please contact digitalscholarship@butler.edu. 


\title{
BOOK REVIEWS
}

\author{
The Unity of Reality: God, God-Experience, and Meditation in \\ the Hindu-Christian Dialogue. Michael von Brück. James V. Zeitz tr. \\ New York: Paulist Press, 1991, 340p., incl. glossary and index.
}

ONE OF THE fundamental problems in theology today is to know how to relate the Christian doctrine of the Trinity to the Hindu experience of non-duality (advaita). Jules Monchanin, the founder of Shantivanam Ashram in India once declared that the focus of the ashram was 'advaita and the Trinity', and his companion Henri le Saux (Swami Abhishiktananda) attempted in his own way, especially in his book Saccidananda, to fathom the mystery; but in his book Michael von Brück, who spent many years in India, has presented the problems with a depth of understanding and a methodical comprehension which has never been achieved before.

$\mathrm{He}$ begins with a careful presentation of the Vedantic philosophy, especially as shown in the teaching of Sankara, the Indian philosopher who is an acknowledged master of advaita Vedanta. He then moves on to a study of the Christian doctrine of the Trinity from the time of the early fathers to the mystics of the Middle Ages - especially Tauler and Suso, leaving out their master Eckhart, as he has already been studied in depth in relation to both Hindu and Buddhist thought. He then shows how Luther's theology was influenced by the study of the mystics, especially through the mystical treatises known as the Theologia Germanica and moves on to a most interesting exposition of the Trinitarian philosophy of Hegel, showing how close it comes to advaita; the study of Karl Barth and other modern German theologians completes this presentation of the doctrine of the Trinity.
He now moves on to what is the main thesis of this book, the presentation of a comprehensive understanding of the Christian Trinity seen in the light of the experience of non-duality. It must be made clear that advaita is not a philosophical theory but an experience of reality, which is normally mediated through the practice of meditation. This is the great difference between the Eastern and the Western approach to reality. The Western mind, following Plato and Aristotle, has normally followed the method of logical deduction, based in Christian theology on the revelation contained in the Bible. The Eastern mind starts from the intuitive experience of reality, but Michael is careful to point. out that intuitive experience, especially the meditative experience of non-duality, must always be rationally developed, as is seen in all the leading schools of Hinduism and Buddhism. There is therefore no question of putting mystical experience in opposition to rational knowledge, but working always towards their integration.

In this way the doctrine of the nonduality of the persons of the Trinity is seen to be based on the understanding of 'perichoresis' (literally the dance), that is the movement of Being itself in its self-expression and self-realisation. In this view, person signifies relationship and the persons of the Trinity are essentially the expression of absolute Being of God in its eternal selfgiving in love. Being expresses itself eternally in the Word, and communicates 


\section{Book Reviews}

itself eternally in the Spirit. We must remember that in using words like this we are using terms of analogy. Humanity is made in the image of God and human consciousness reflects the original being and consciousness from which it comes. Such language points towards or indicates a reality which our human mind reflects.

But lest this should appear as a merely metaphysical concept of God, Michael emphasises how it is based on the Incarnation in Christ. In Christ the eternal reality, which is also pure consciousness, expresses and communicates itself in a movement analogous to its eternal expression and communication in the Trinity. In this way human history, including all human sin and misery, is seen to be integral to the unfolding life of the Trinity. We have to remember that in expressing himself in his Word the Godhead expresses the whole universe and all humanity, which are a reflection of the infinite being and consciousness of God.

But above all we have to realise that all these relationships which constitute the inner life of the Trinity are 'non-dual' relationships. The eternal Being differentiates itself in consciousness, but at the same time always remains absolutely one. This is obviously a mystical insight and we have to recognise that all theology points toward a transcendent reality which is beyond word and thought.

THIS BOOK IS inter-religious dialogue that draws on Advaitic thought in developing a Christian mystic theology. Some sections of it are quite dense and even convoluted at times, and the comparative parallels are not always persuasive. Nevertheless, the essential thrust of von Brück's argument is penetrating and seems in many respects a cogent proposal. He focuses on the transformative power of the Advaitic non-duality experience, suggesting that it is an existential realisation which corresponds to and illuminates
We are being challenged today, as Pere de Lubac said to Fr. Monchanin, to rethink everything in terms of theology and to rethink theology in terms of mysticism.

It is impossible in a short review to do more than indicate the immeasurable riches to be found in this understanding of the trinity as the universal ground of all reality. Nothing in the universe, including sin, suffering and death, as reflected in the crucifixion of Christ, is outside the mystery of the Trinity. It reflects the dynamism of love which permeates the whole creation. We are all involved at all times in the mysterious process, by which the eternal reality manifests itself in all creation and draws every creature out of its immersion in the spatiotemporal world into its own eternal life, thus reconciling all opposites; and revealing the essential 'unity of reality'.

It should be added that this is a translation from German. How accurate it is I cannot say, but the translator has succeeded in putting in clear and concise English the extremely rich and complex thought contained in this extraordinary book. I can only recommend all those who are concerned with the evolution of theology today to study this book and see for themselves the depths of insight which it brings.

\section{Bede Griffiths}

aspects of the apophatic experience of the Christian Trinity. 'Perichoresis' (dance) describes the 'mutual permeation' of the Persons of the Trinity (p.87). It characterises the 'polar movement' between the unity in transforming the consciousness of the mystic. In Part II of the book, this trinitarian perichoresis is illustrated in reference to Irenaeus, Tertullian, Origen, Athanasius, Gregory of Nyssa, John Damascene, Augustine, The Cloud of Unknowing, Suso, and Tauler. Also, von Brück attempts to clarify his view in dialogue with Tillich, 
Luther, Hegel, Barth, Pannenberg and Moltmann, and he makes extensive references to a wide variety of secondary material.

The Trinity symbolises the dialectic between apophatic and cataphatic God: it is the process of unity in distinction, wherein the three Persons perichoretically reveal the essential unity of the Divine. This perichoretic revelation cannot be comprehended through transitive thought but only experienced in an 'intransitive becoming conscious' (p.78). In meditative experience the mystic participates in the perichoresis of trinitarian non-duality. Von Brück goes on in Part III to develop an epistemological framework for the trans-subjective experience, one that involves personal, self-transformative methods of verification. Meditative consciousness is a spiritual experience that encompasses both mental and sensual consciousness. Advaitic unity is 'understood not as a statement, but as a self-realising process' (p.183). Evidence of its epistemological and ontological primacy is found in its transformative consequences: reflecting the perichoretic Trinity, the united consciousness 'integrates all of reality in contemplative receptivity' (191). The mystic's consciousness is transmuted in advaitic unity, and she expresses elements of the Divine in daily life.

For von Brück, Christian prayer and Yogic meditation mutually inform each other in an ascending hierarchy of petition, praise, personally transformative prayer, and finally contemplative concentration. Contemplation corresponds to objectless meditation, the stripping away (kenosis) of images, categories, and the egocentric will, and the plunge into the dark nothingness of the infinite abyss. Advaitic unity is the identification with nirguna Brahman or Father. But for von Brück this is the 'eternal unity of the many', 'the unity of possibility and realisation' (p.151). The experience does not culminate in static and amoral 'nothingness', but leads to the 'experience of Jesus as he is in himself; namely, as a center within the trinitarian love' (p.189). Human conscious- ness is integrated and harmonised in the unitive experience, and the mystic actively expresses, like Jesus as exemplar of kenosis, positive and personal elements of the Trinity.

Von Brück attempts to illuminate the perichoretic processes in reference to a wide variety of Advaitic doctrine which he develops in Part I. But not all the parallels are clear or cogent. I think confusions arise in part from various ambiguities in Advaita Vedanta itself. Von Brück's thesis is a Christian perspective which maintains the essential value of creation, personality and community. He admits that some Advaitans depict the world, personality and history as illusion, hence failing to integrate saguna Brahman into the unitive experience. Yet he postulates a 'transpersonal person' as the Absolute in Advaita and insists upon theistic elements. He maintains that Advaita does not espouse a monistic ideal, he speaks of moksa as the fruition of empirical reality' (p.68) and suggests there is a purpose to Maya. Moreover, he ascribes an ontological connection between saguna and nirguna Brahman and says that bhakti yoga is indispensable to the unitive ideal in Advaita. But even if we stretch to the limits the most creative Advaitic perspectives, it seems difficult to maintain that 'we can present the experience of [Advaitic] non-duality as a melting away of the human self in the ecstasy of the unity of love based on divine grace' (p.64). I think that a comparison between von Brück's reading of Advaita and Ramanuja's Visistadvaita Vedanta would prove most revealing in this regard. Indeed, von Brück perceives an irreversible dependence of atman upon Brahman (tadatmya), and a relationship in the non-duality of Advaita. $\mathrm{He}$ says: 'each person is an atman who is neither identical with nor different from the Absolute, but in a particular relationship of non-duality to it' (p.137).

I suspect that von Brück would find stronger parallels to trinitarian perichoresis in other forms of Vedanta. Moreover, it is not always clear to the reader just where von Brück's reading of Advaita transforms into 
the 'creative integration' of his own Christian, theistic perspective. But it is clear that in establishing some correlations between Advaitic and Christian mystical experience von Brück firmly locates spiritual experience at the forefront of inter-religious dialogue. From a Christian standpoint, intra-trinitarian, perichoretic transformation illustrates the 'trans-historical power of the Spirit'. (p.263) and moves the terms of conversion away from cognitive beliefs that are sociohistorically conditioned, to experiences of the Spirit which are not exclusive to Christianity. As von Brück puts it: "The "how" and "where" of this realisation cannot be confined to our theological pronouncements and church walls' (p.265).

Von Brück sees the Christ event as a limited 'historical accident' that qualitatively transforms history in that this aspect of the Trinity becomes the integrating factor in trinitarian perichoresis. Although the effects of this event are not exclusive to the western world, the personal and active experience of Christ is the natural extension of the nonduality of Advaita. It draws the historical into the contemplative mode and integrates the socio-historical with the unitive experience. But Advaita provides insight into the nature of the trinitarian unity, as well as the spiritual means necessary to the peri- choretic movement. Moreover, von Brück insightfully adapts from Advaita a doctrine of rebirth, one which he deems necessary to coherent theodicy. He addresses traditional Christian theological objections to rebirth and criticises popular misconceptions as well as Advaitic perspectives which deny the reality of samsara. His views on spiritual growth and the socio-communal ideal of Christian perichoretic transformation require the postulation of a unique personal centre of the individual, and the rebirth into this particular realm of existence in progressive movement towards the perichoretic ideal.

Von Brück's theological development should stimulate discussion on a number of controversial issues: the relation of his mystic theology to more mainstream Christian perspectives; his stress on personal spiritual experience and the epistemology thereof; his interpretation of Advaitic doctrine; and his views on religious truth, rebirth, the Christ, proselytism, and the nature of inter-religious dialogue. The Unity of Reality is a provocative and significant book.

\author{
Michael Stoeber \\ Catholic University of America \\ Washington, D.C.
}

\section{The Law of Karma. Bruce R. Reichenbach. Honolulu: University of Hawaii Press, 1990, 238p.}

\section{THE LAW OF Karma is a facet of Indian} thought which is known best to the West but is understood the least. The book under review has all of the requisites to change that.

The philosophical approach of the book sets it apart from recent contributions to the field that follow historical and anthropological lines. It is also distinguished by addressing the issues of karma in its total Indian setting, and by delving into the subject as 'a living thesis' that goes beyond the classical documents to the exposition of contemporary scholars.

Because this doctrine is a master key that opens many other religious and philosophical doors, the reader is ushered into numerous chambers that discuss the Law of Karma in relation to its Metaphysical Presuppositions; to the Law of Universal Causation; to Fatalism; to the Problem of Evil; to Causation and Divine Intervention; 